\title{
Intellectual Capital Disclosure and Post-Pandemic Market Performance in the Manufacturing Industry
}

\author{
Temy Setiawan ${ }^{1}$, Rustono Farady Marta $^{2}$, Andreas Heryjanto ${ }^{3}$, Danang Trijayanto ${ }^{4}$, \\ Abhirama Swastyayana Dian Perdana ${ }^{5}$ \\ Universitas Bunda Mulia, Jln. Lodan Raya No. 2, North Jakarta, 14430, Jakarta, Indonesia ${ }^{1,2,3}$, \\ Universitas 17 Agustus 1945, Jl. Sunter Permai Raya, North Jakarta, 14350, Jakarta, Indonesia ${ }^{4}$, \\ President University, Jln. K.H. Dewantara, Kota Jababeka, Bekasi, 17550, West Java, Indonesia ${ }^{5}$ \\ tsetiawan@bundamulia.ac.id ${ }^{1}$,rmarta@bundamulia.ac.id², aheryjanto@bundamulia.ac.id ${ }^{3}$ \\ danang.triyanto@uta45jakarta.ac.id ${ }^{4}$,perdana.abhirama@president.ac.id ${ }^{5}$
}

\begin{abstract}
Currently, the condition of Indonesia's manufacturing industry is experiencing major problems, not only the existence of an international trade war, but also the outbreak of COVID-19 causing a volatile stock market. This study aims to examine the effect of Intellectual Capital Disclosure (ICD) on market performance directly or with profitability as a mediator. ICD shows the role of industrial innovation and infrastructure in achieving the ninth goal of the Sustainability Development Goals (SDGs). The study's population was all manufacturing companies in Indonesia with a total sample of 64 companies for 5 years of research (2015-2019). Secondary data were obtained from annual reports taken from the official website of the Indonesia Stock Exchange. Data collection technique was content analysis for ICD indicators. The method of analysis was using Smart PLS. The results showed that ICD has an influence on market performance and profitability was proven to mediate.
\end{abstract}

Keywords: Content Analysis, Intellectual Capital Disclosure, Market Performance, COVID-19 Pandemic, Profitability

\section{Introduction}

Market performance is a measurement of a management's success in managing business ventures [1][2][3][4]. The measurement of market performance for companies listed on the Indonesia Stock Exchange can be reflected in the market value of the traded shares [5][6].

Research related to market performance is important because the stock market conditions are quite volatile [7][8]. There are external and internal factors that influence market performance. External factors such as the macro economy, and even the world's problems today - the COVID-19 pandemic - also influence market performance [9]. These factors can be said as uncontrollable factors. However, there are internal factors that tend to be controllable by the company, such as financial performance. Because internal factors are controllable, this study is limited to research on internal factors that affect company performance.

Another factor that is predicted to influence market performance is Intellectual Capital (IC). If the company has an IC and manages it well, it will have an impact on the company's market value [10][11]. In addition, if IC is a valuable resource for competitive advantage, then it will contribute to the company's performance in terms of both financial performance and market performance [12][13]. In communicating IC to stakeholders, of course the financial reporting media is the main thing. The company will disclose the IC in its annual report. 
Although still voluntary, the level of urgency is currently very high for users of financial statement information in making decisions, especially investors. Therefore, this research is paramount to prove the influence of Intellectual Capital Disclosure (ICD) on market performance.

The purpose of this research is to provide empirical evidence that ICD has an influence on market performance. Second, the research provides empirical evidence that profitability, which is part of financial performance measurement, mediates the influence of IC on market performance.

This research also provides several benefits. First, this research adds a reference to the ICD research on market performance in the manufacturing industry in Indonesia. This study limits on the manufacturing industry because the manufacturing industry is the main growth engine that dominates companies listed on the Indonesia Stock Exchange (IDX) as well as an industry that can absorb more labor than other sectors. Therefore, the manufacturing sector is expected to continue to grow so that economic growth continues to rise[14].

The weakening of the manufacturing industry and economic growth cannot be separated from external factors. As we know, the current global situation is full of uncertainty with the existence of trade war between the United States (US) and China, indirectly resulting in a decreased demand for production in Indonesia [15]. In addition, the condition is exacerbated by the existence of COVID-19 pandemic that swept the world from across sectors, due to the suggestion to carry out personal quarantine and travel restrictions [16].

A number of studies have examined the influence of ICD on company performance $[17][18][19][31]$, the influence of ICD on profitability [20][21][22][3][23][32][33]and profitability to company value [24][13][34][35]. However, there are still gaps between those that explain there are positive, negative, or whether there is no influence. Each of these studies is very interesting to study and prove empirically because: (1). There is still a gap in results as previously explained; (2). The manufacturing industry is currently shaking; (3). ICD in Indonesia is still voluntary, but their urgency is increasing.

\section{Literature Review}

\subsection{Market Performance}

In this study, Tobin's $\mathrm{Q}$ is used in measuring market performance because Tobin's Q represents a picture of management's performance in managing funding sources to finance company assets measured by market value in its equity [25][26].

$$
\operatorname{Tobin}^{2} s Q=\frac{(M V E+D)}{T A}
$$

\subsection{Intellectual Capital Disclosure (ICD)}

ICD is a report issued by a company that aims to meet the information needs of stakeholders[27]. According to Ulum [28], Intellectual Capital Disclosure (ICD) is divided into 3 categories of disclosure sizes, i.e. human capital consisting of 8 items, structural capital disclosure consisting of 15 items, and relational capital disclosure consisting of 13 items. 


\subsection{Profitability}

In this study, the formula used is ROA measured by net income divided by total assets [29].

$$
R O A=\frac{\text { Net income after tax }}{\text { Total Asset }}
$$

\subsection{Hypothesis Submission}

Based on the resource-based theory proposed by Bontis and Richardson[30], the resources possessed both tangible and intangible have the potential to create excellence that will encourage the formation of competitive advantage. This is a strategy for companies to win a business competition. Advantages derived from these resources will improve market performance. The intended advantage of these intangible resources is IC. ICD has a paramount role in improving market performance because it affects the positive perception of investors in decision making through the information presented in the financial statements.

\section{$\mathrm{H}_{1}$ : there is an influence of ICD on market performance}

The existence of ICD will increase profitability because with ICD it means that the company has increased its intangible asset capability within the company as much as possible. With an increase in IC, it causes an increase in the effectiveness and productivity of owned resources. Thus, the company's profits will also increase.

\section{$\mathrm{H}_{2}$ : there is an influence of ICD on profitability}

Profitability tends to improve market performance because companies that have high ROA will signal that management performance is good and attracts investors' attention. This has an impact on increasing share prices and a positive impact on market performance as measured by Tobin's Q. This is in line with the results of Prima et al.'s study [13].

$\mathrm{H}_{3}$ : there is an influence of profitability on market performance

ICD will have an influence market performance because the information revealed in the annual report gives confidence to stakeholders, especially investors, about the company's capabilities in managing its resources. However, if analyzed indirectly, ICD will affect the profitability of the company because of the maximization of the resources owned by the company. An increase in profitability will influence market performance through an increase in stock prices. This is due to investors being attracted to companies that have high profitability[32][20][36][24].

H4: ICD has an influence on company value with profitability as a mediating variable.

\section{Method}

The subjects of this study were manufacturing companies listed on the Indonesia Stock Exchange (IDX) for the 2015-2019 period. Various visibility reports can be accessed properly through the site as a database through a cloud computing system [37]. The use of data presented to the public is strived to have systemized access eligibility [38] and connectivity between users through a qualified network management to produce data availability [39]. Data availability in the system understood in the realm of Information and Communication Technology (ITC) certainly needs to also be understood by its readability for users, especially in the industry [40]. This readability is also used as secondary data and data collection techniques is using literature study and content analysis (CA) in making ICD scores. [41]. 


\section{Results and Discussion}

\subsection{Measurement Model (Outer Model)}

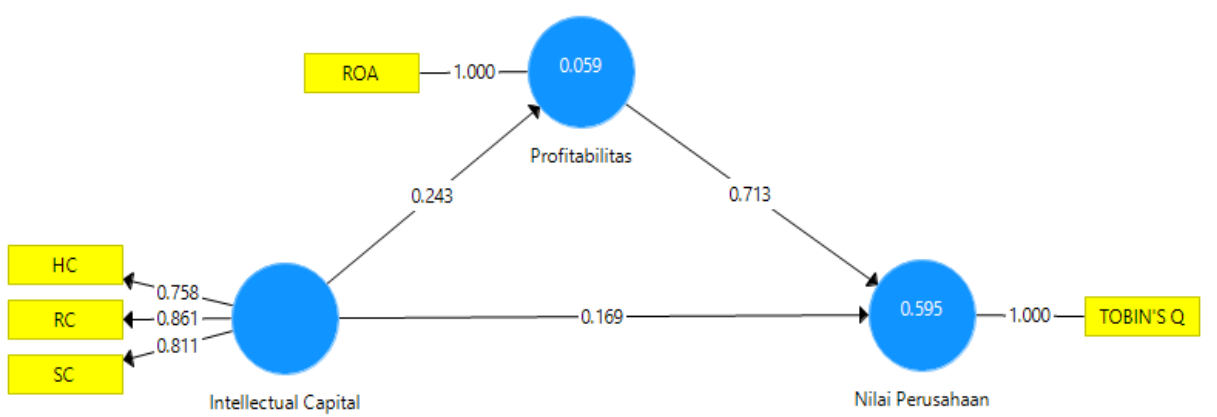

Fig.1. Measurement Model (Outer Model)

Source: Data were processed using SmartPLS 3.0

Test conducted on the outer model is Convergent Validity. From Figure 1., it can be seen that all loading factor values of each latent variable are above 0.6. This means that there is no loading factor problem [42].

\subsection{Structural Model (Inner Model)}

Evaluation of inner models can be done in three ways, i.e. by looking at R2, Q2, and GoF.

Table 3. Presentation of Discriminant Validity Results

\begin{tabular}{lcc}
\hline & R Square & R Square Adjusted \\
\hline Value of Company & 0.605 & 0.694 \\
Profitability & 0.259 & 0.256 \\
\hline \multicolumn{2}{c}{ Source: Data were processed using Smart PLS 3.0 }
\end{tabular}

The resulting R2;Q2 and GoF are at high level value $(0.694 ; 0.6177 ; 0.7336)$ so this model can be said as good for predicting. Therefore, hypothesis testing can be done.

\subsection{Hypothesis testing}

A variable is said to have an influence on other variables if the p-value of the relationship/path is below 0.05 .

Table 4. Presentation of Path Coefficients Results

\begin{tabular}{lccc}
\hline & Original sample & T Statistic & P value \\
\hline ICD - Market performance & 0.169 & 3.662 & 0.000 \\
ICD - Profitability & 0.243 & 4.444 & 0.022 \\
Profitability - Market & 0713 & 11.601 & 0.000 \\
Performance & & & \\
\hline
\end{tabular}

Source: Data were processed using Smart PLS 3.0

From the table above, it can be concluded that there are: (1) an influence of ICD on market performance; (2) an influence of ICD on profitability; (3) an influence of profitability on 
market performance; and (4) an influence of ICD on market performance with profitability as a mediator.

This explains that the information revealed in the annual report related to IC has an influence on stakeholders, especially investors so that the stock price rises in line with stakeholder theory [12]. Therefore, ICD needs to be the concern of the company to stimulate market performance through market prices. This is because ICD is an internal factor that can be controlled by the company.

It is proven that ICD influences profitability. Companies that improve ICD certainly have an increase in the quality of IC that encourages the effectiveness of strategy and resource productivity. Therefore, this condition encourages profitability.

It can be stated that profitability has a significant effect on market performance, so that $\mathrm{H} 3$ is accepted. Companies that have a high profitability ratio tend to receive stakeholder confidence so that the value of the company will increase.

The influence of ICD on market performance with profitability as a mediator to see whether profitability is able to mediate the relationship between ICD according to [43] and [44], is acquired by multiplying the loading factor of ICD on profitability and loading factor profitability on market performance, so the results obtained 0.173 . Then, these results are compared with the results of loading factor and the relationship between ICD with market performance which shows the results of 0.169 . From this comparison it can be stated that there is an indirect relationship (value $0.173>0.169$ ) so that profitability is proven to mediate.

\section{Conclusion}

From the results of this study, it appears that ICD influences market performance either directly or through profitability as a mediator. This is because the ICD increases investor confidence both because of a transparency in the ability of the management in the resources management as well as an increase in effectiveness and productivity that encourages increased profits and ultimately stock prices. Therefore, further research can actually analyze the manufacturing companies, i.e. what are the factors that encourage companies to make disclosure of the current intellectual capital. For companies, they are expected to pay attention whether the ICD is in line with the 9th goal in the SDGs. Although the ICD is still voluntary, it is proven that the urgency is quite high in improving management performance and the information conveyed through financial statements will be beneficial to stakeholders, especially investors, to make investment decisions.

\section{References}

[1] S. M. Williams, "Is Intellectual Capital Performance and Disclosure," J. Intellect. Cap., vol. 2, no. 3, pp. 192-203, 2001, doi: 10.1108/14691930010348731.

[2] L. J. Gitman, C. J. Zutter, W. Elali, and A. Al Roubaie, Principles of Managerial Finance, Arab World. England: Pearson Education Ltd, 2013.

[3] R. Suherman, "The Impact of Intellectual Capital toward Firm's Profitability and Market Value of Retail Companies Listed in Indonesia Stock Exchange (IDX) from 2013-2016," iBuss Manag., vol. 5, no. 1, pp. 98-112, 2017, [Online]. Available: http://publication.petra.ac.id/index.php/ibm/article/view/5877.

[4] Z. Fadri, "Pengaruh Intellectual Capital terhadap Profitabilitas dan Produktivitas pada 
Perbankan Syariah di Indonesia," J. Ilmu dan Ris. Akunt., vol. 5, no. 11, pp. 1-18, 2016, doi: 10.1017/CBO9781107415324.004.

[5] D. Sirinuch Nimtrakoon, Ph, "The Relationship Between Intellectual Capital, Firms' Market Value and Financial Performance: Empirical Evidence From Asian Countries," J. Intellect. Cap., vol. 16, no. 3, pp. 587-618, 2015, doi: https://doi.org/10.1108/JIC-09-2014-0104.

[6] A. D. Rahmawati, Topowijono, and S. Sulasmiyati, "Pengaruh Ukuran Perusahaan, Profitabilitas, Struktur Modal, dan Keputusan Investasi Terhadap Nilai Perusahaan (Studi pada Perusahaan Sektor Properti, Real Estate, dan Building Construction yang Terdaftar di Bursa Efek Indonesi (BEI) Periode 2010-2013)," J. Adm. Bisnis, vol. 23, no. 2, pp. 1-7, 2015, [Online].

Available: http://administrasibisnis.studentjournal.ub.ac.id/index.php/jab/article/view/924.

[7] S. Hermuningsih, "Pengaruh Profitabilitas, Growth Opportunity, Struktur Modal terhadap Nilai Perusahaan pada Perusahaan Publik di Indonesia," Bul. Ekon. Monet. dan Perbank., pp. 127 148, 2013, doi: 10.1177/027046769801800106.

[8] F. C. Yulianto and A. Subardjo, "Pengaruh Likuiditas, Solvabilitas, Aktivitas dan Profitabilitas terhadap Nilai Pasar,” J. Ilmu dan Ris. Akunt., vol. 6, no. 1, pp. 187-202, 2017, [Online]. Available: http://jurnalmahasiswa.stiesia.ac.id/index.php/jira/article/view/748.

[9] T. Setiawan and H. S. Sundoro, "How Is the Effect of Inflaction to Interest Rate, Exchange Rate and Indonesia Composite Index?,” Res. J. Financ. Account., vol. 10, no. 10, pp. 70-76, 2019, doi: $10.7176 /$ RJFA.

[10] A. Halim, H. Basri, and Faisal, "Pengaruh Intellectual Capital terhadap Profitabilitas dan Dampaknya terhadap Harga Saham Perusahaan Sektor Keuangan yang Terdaftar di Bursa Efek Indonesia (BEI)," J. Bisnis dan Ekon., vol. 23, no. 2, pp. 124-141, 2016, [Online]. Available: https://www.unisbank.ac.id/ojs/index.php/fe3/article/view/4973.

[11] A. D. Pangestu and R. E. Wijaya, "Pengaruh Intellectual Capital terhadap Market Value dan Kinerja Keuangan,” J. Account. Invetment, vol. 15, no. 2, pp. 90-100, 2014, [Online]. Available: https://journal.umy.ac.id/index.php/ai/article/view/1329.

[12] D. I. Ulum, Intelectual Capital: Model Pengukuran, Framework Pengungkapan, dan Kinerja Organisasi. Malang: Universitas Muhammadiyah Malang, 2017.

[13] R. Prima, R. P. Ananto, and M. Rafi, "Pengaruh Struktur Modal, Profitabilitas, Ukuran Perusahaan dan Modal Intelektual terhadap Nilai Perusahaan pada Indeks LQ 45 Periode 20102017," J. Akunt. Manaj., vol. 13, no. 2, pp. 93-111, 2018, doi: https://doi.org/10.30630/jakmenpnp.13.2.136

[14] S. R. D. Setiawan, "Kinerja Manufaktur Merosot, Apa Dampaknya ke Pertumbuhan Ekonomi," Kompas.com, p. 1, Oct. 02, 2019.

[15] I. U. Aldin, "Indeks Manufaktur Turun Drastis Perberat Laju IHSG Pekan Ini," katadata.co.id, Jakarta, p. 1, Nov. 01, 2019.

[16] M. Chinmi, R. F. Marta, C. G. Haryono, J. Fernando, and J. K. Goswami, "Exploring Online News as Comparative Study Between Vendatu at Indiaand Ruangguru From Indonesia In Covid-19 Pandemic," J. Content, Community Commun., vol. 11, pp. 167-176, 2020, doi: 10.31620/JCCC.06.20/13.

[17] D. Ardianto and M. Rivandi, "Pengaruh Enterprise Risk Management Disclosure, Intellectual Capital Disclosure dan Struktur Pengelolaan terhadap Nilai Perusahaan," Profita Komun. Ilm. Akunt. dan Perpajak., vol. 11, no. 2, pp. 284-305, 2018, doi: 10.22441/profita.2018.v11.02.009.

[18] I. G. A. P. Oktari, E. Widiastuty, and L. Handajani, "Determinan Modal Intelektual (Intellectual Capital) pada Perusahaan Publik di Indonesia dan Implikasinya terhadap Nilai Perusahaan," Simp. Nas. Akunt. XIX, pp. 1-29, 2016, [Online]. Available: http://eprints.unram.ac.id/15998/.

[19] K. Y. M. D. Isvara, M. A. Wahyuni, and P. Julianto, "Pengaruh Intellectual Capital terhadap Nilai Perusahaan dengan Kinerja Keuangan Sebagai Variabel Intervening (Studi Perusahaan Manufaktur pada Bursa Efek Indonesia Periode 2013-2016)," E-Jurnal S1 Ak Univ. Pendidik. Ganesha, vol. 8, no. 2, pp. 50-56, 2017, [Online]. Available: https://ejournal.undiksha.ac.id/index.php/S1ak/article/view/14660.

[20] M. M. Martins and I. T. Lopes, "Intellectual Capital and Profitability: A Firm Value Approach 
in the European Companies," Verslas Teor. ir Prakt. /bus. Theory Pract., vol. 17, no. 3, pp. 234-242, 2016, doi: 10.3846/btp.2016.673.

[21] R. Harianti and I. Wijaya, "Pengaruh Intellectual Capital terhadap Profitabilitas Industri Makanan dan Minuman di BEI Periode 2011-2015," Konf. Ilm. Akunt. IV, vol. VIII, pp. 38-54, 2017, [Online]. Available: https://www.academia.edu/37108137/Pengaruh_Intellectual_Capital_Terhadap_Profitabilitas_I ndustri_Makanan_dan_Minuman_Di_BEI_Periode_2011-2015?auto=download.

[22] M. F. Faza and E. Hidayah, "Pengaruh Intellectual Capital terhadap Profitabilitas, Produktivitas, dan Nilai Perusahaan pada Perusahaan Perbankan yang Terdaftar di Bursa Efek Indonesia (BEI)," EKBISI, vol. VIII, no. 2, pp. 186-199, 2014, [Online]. Available: http://ejournal.uinsuka.ac.id/syariah/Ekbisi/article/view/355.

[23] A. Agusta and A. S. Adiwibawa, "Analisis Pengaruh Modal Intelektual terhadap Profitabilitas, Produktifitas, dan Penilaian Pasar Perusahaan (Studi Kasus Pada 35 Perusahaan LQ-45 di Bursa Efek Indonesia Periode 2012-2014)," Diponegoro J. Account., vol. 6, no. 2, pp. 1-11, 2017, [Online]. Available: https://ejournal3.undip.ac.id/index.php/accounting/article/view/18238.

[24] G. Tarima, T. Parengkuan, and V. Untu, "Pengaruh Profitabilitas, Keputusan Investasi dan Keputusan Pendanaan terhadap Nilai Perusahaan Farmasi yang Terdaftar di Bei Periode 20112014,” J. Berk. Ilm. Efisiensi, vol. 16, no. 4, pp. 465-474, 2016, [Online]. Available: https://ejournal.unsrat.ac.id/index.php/jbie/article/view/13629.

[25] A. C. A. Sauaia and F. H. F. C. Junior, "Is the Tobin'S a Good Indicator of a Company'S Performance,” Dev. Bus. Simul. Exp. Learn., vol. 29, pp. 301-307, 2002, [Online]. Available: https://journals.tdl.org/absel/index.php/absel/article/view/789.

[26] L. Fu, R. Singhal, and M. Parkash, “Tobin's q Ratio and Firm Performance," Int. Res. J. Appl. Financ., vol. VII, no. 4, pp. 1-10, 2016, doi: 10.4088/JCP.11m07074.Effectiveness.

[27] Istianingsih and S. Utama, "Prediksi Laba Masa Depan Perusahaan Melalui Pengungkapan Modal Intelektual," Akuntabilitas, pp. 121-142, 2015, [Online]. Available: http://lib.ibs.ac.id/materi/Prosiding/SNA XVIII/makalah/017.pdf.

[28] I. Ulum, "Intellectual Capital Disclosure: Suatu Analisis Dengan Four Way Numerical Coding System," J. Akunt. Audit. Indones., vol. 19, no. 1, pp. 39-50, 2015, doi: 10.20885/jaai.vol19.iss1.art4.

[29] J. C. Van Horne and J. John M. Wachowicz, Fundamentals of Financial Management PrinsipPrinsip Manajemen Keuangan, 12th ed. Jakarta: Salemba Empat, 2007.

[30] D. N. Bontis, W. C. C. Keow, and D. S. Richardson, "Intellectual Capital and Business Performance in Malaysian Industries," J. Intellect. Cap., vol. 1, no. 1, pp. 85-100, 2000, doi: $10.1108 / 14691930010324188$.

[31] Susanti, "Pengaruh Intellectual Capital Terhadap Nilai Perusahaan Perbankan di Bei Periode 2013-2015,” J. Bisnis Darmajaya, vol. 2, no. 2, pp. 146-159, 2016, [Online]. Available: https://jurnal.darmajaya.ac.id/index.php/JurnalBisnis/article/download/713/463.

[32] D. N. S. Werastuti, "Model Moderasi dalam Hubungan antara Intellectual Capital Discloure, Nilai Perusahaan, dan Financial Performance," J. Keuang. dan Perbank., vol. 18, no. 1, pp. 1428, 2014, [Online]. Available: http://jurnal.unmer.ac.id/index.php/jkdp/article/view/768.

[33] S. Radić, "The Impact of Intellectual Capital on the Profitability of Commercial Banks in Serbia," Econ. Ann., vol. 63, no. 216, pp. 85-109, 2018, doi: 10.2298/EKA1816085R.

[34] D. Wulandari, P. Dhiana, and A. Suprianto, "Pengaruh Modal Intelektual, Struktur Modal, Profitabilitas, terhadap Nilai Perusahaan dengan Kinerja Keuangan Sebagai Variabel Intervening," J. Account. J. Ilm. Mhs. S1 Akunt. Unpand, vol. 4, no. 4, pp. 1-14, 2015, doi: 10.12816/0013114.

[35] A. Pujianto, W. Utami, and I. Sastrodiharjo, "Peran Life Cycle Stage dalam Memoderasi Hubungan antara Intellectual Capital Disclosure dan Nilai Perusahaan," Akuntabilitas, vol. 9, no. 1, pp. 121-142, 2016, doi: 10.15408/akt.v9i1.3588.

[36] Nuryaman, "The Influence of Intellectual Capital on The Firm's Value with The Financial Performance as Intervening Variable," Procedia - Soc. Behav. Sci., vol. 211, pp. 292-298, 2015, doi: 10.1016/j.sbspro.2015.11.037. 
[37] R. Rahim, E. F. Armay, D. Susilo, R. F. Marta, and A. Alanda, "Cloud Computing Security Issues and Possibilities," Int. J. Eng. Adv. Technol., vol. 8, no. 6 Special Issue, pp. 927-931, 2019, doi: 10.35940/ijeat.F1175.0886S19.

[38] R. Farady Marta et al., "Author Compliance in Following Open Journal System of Communication Science in Indonesia," J. Phys. Conf. Ser., vol. 1175, no. 6s, pp. 1-10, 2019, doi: 10.1088/1742-6596/1175/1/012222.

[39] R. F. Marta, G. S. Achmad Daengs, A. Daniar, W. O. Seprina, and A. P. Menayang, "Information Security Risk and Management in Organizational Network," Int. J. Eng. Adv. Technol., vol. 8, no. 6 Special Issue 2, pp. 1152-1156, 2019, doi: 10.35940/ijeat.F1286.0886S219.

[40] H. Tannady, Resdiansyah, J. F. Andry, and R. F. Marta, "Exploring the Role of ICT Readiness and Information Sharing on Supply Chain Performance in Coronavirus Disruptions," Technol. Reports Kansai Univ., vol. 62, no. 5, pp. 2581-2588, 2020, [Online]. Available: https://www.kansaiuniversityreports.com/article/exploring-the-role-of-ict-readiness-andinformation-sharing-on-supply-chain-performance-in-coronavirus-disruptions.

[41] T. Setiawan, Y. Z. Basri, Y. A. Sudibyo, A. Purwanti, and J. Gunawan, "A Development of Sustainability Disclosure Practices in the Mining Oil and Gas (MOG) Industries: a Study From Indonesia," J. Econ. Sustain. Dev., vol. 9, no. 14, pp. 35-46, 2018, [Online]. Available: https://iiste.org/Journals/index.php/JEDS/article/view/43417.

[42] I. Ghozali and H. Latan, Partial Least Squares : Konsep, Teknik dan Aplikasi Menggunakan Program SmartPLS 3.0 Untuk Penelitian Empiris. Semarang: Badan Penerbit Universitas Diponegoro, 2015.

[43] R. M. Baron and D. A. Kenny, "The Moderator-Mediator Variable Distinction in Social Psychological Research: Conceptual, Strategic, and Statistical Considerations," J. Pers. Soc. Psychol., vol. 51, no. 6, pp. 1173-1182, 1986, doi: 10.1177/1350506818764762.

[44] R. Pardede and R. Manurung, Analisis Jalur (Path Analysis) : Teori dan Aplikasi dalam Riset Bisnis. Jakarta: PT Rineka Cipta, 2014. 